\title{
Essential Hypertension in Ten \& Half Years Old Boy: A Case Report
}

\author{
Roy RR ${ }^{1}$, Qader $\mathrm{MA}^{2}$, Matin $\mathrm{A}^{3}$, Islam $\mathrm{MR}^{4}$, Begum $\mathrm{A}^{5}$
}

\begin{abstract}
Childhood hypertension (HTN) is important cause of morbidity and mortality. Most of the cases of childhood HTN are secondary to an underlying disorder. In this case report a ten \& half yr old boy presented with neck pain associated with headache. Both of his parents are hypertensive. Most of the time he spent at home playing games in computer and watching television. On examination, blood pressure (BP) was 140/95 mm of $\mathrm{Hg}$ which was above 99th percentile for his age and height. Examination of eyes and other systems revealed normal. Ultrasonography of abdomen was normal, colour Doppler ultrasonography of renal vessels showed normal, and CT scan of abdomen was also normal including normal adrenal gland and sympathetic chain. Then the child was treated with tab. losartan potassium, then gradually BP become bellow 90th percentile. Ultimately the child was discharged when his blood pressure was $100 / 70 \mathrm{~mm}$ of $\mathrm{Hg}$, which was on 50th percentile with counselling and advised for follow up. [J Shaheed Suhrawardy Med Coll, 2013;5(1):69-71]
\end{abstract}

Key Words: Essential hypertension, childhood hypertension,

Received: December 2012; Revised: March 2013; Accepted: May 2013

\section{Introduction}

Childhood hypertension (HTN) has become an important health issue due to its rising prevalence and associated sequelae. Most of the cases of childhood HTN is secondary to an underlying disorder, like renal, endocrine and cardiovascular or may be due to some drugs ${ }^{1,2}$. Recent reports suggest an increased prevalence of childhood HTN, particularly essential $\mathrm{HTN}^{3}$. HTN in US children has increased, affected up to $5 \%$ of adolescents ${ }^{4}$. Prevalence of HTN in other countries has been reported to be between 1 and $22 \%{ }^{4,5}$. Hospital based study shows more primary HTN which is about $22.7 \% \%^{6}$. but in screening study among school children shows prevalence of primary HTN $0.46-11.7 \%{ }^{7}$. Essential HTN is the most common form of HTN in adults and it is recognised more often in adolescent than in younger children ${ }^{8}$. Essential HTN is a diagnosis of exclusion'. Significant risk factors for essential HTN include family history of HTN and increased $\mathrm{BMI}^{9}$. In the year 2001, 7.6 million premature deaths were attributed to HTN worldwide ${ }^{10}$. Roughly half of the stroke and ischemic heart disease events occur during the same period.

\section{Case Report}

A ten \& half yr old boy who was previously in good health 3 months back, developed neck pain and decreased sleep. Neck pain was gradually increasing in intensity, later on associated with headache, which was so worsening that disrupts his daily activity. He had no history of haematuria, oligouria, fever, rash, joint pain or convulsion. Both of his parents are hypertensive and they have dyslipidemia. Most of the time he spent at home playing games in computer and watching television. He preferred to take fast foods regularly in home and also his tiffin at school. On examination, he was well alert; all the vital signs were within normal limit except blood pressure (BP) which was 140/95 $\mathrm{mm}$ of $\mathrm{Hg}$, above 99th percentile for his age and

1. Dr. Ranjit Ranjan Roy, Associate Professor, Department of Pediatric Nephrology, Bangabandhu Sheikh Mujib Medical University, Dhaka

2. Dr. Md. Abdul Qader, Resident (Phase-B), Department of Paediatric Nephrology. Bangabandhu Sheikh Mujib Medical University, Dhaka

3. Dr. Abdul Matin, Assistant Professor, Department of Pediatrics, Shaheed Shurawardy Medical College, Dhaka

4. Dr. Md. Rafiqul Islam, Associate Professor, Department of Pediatrics, Shaheed Shurawardy Medical College, Dhaka

5. Dr. Afroza Begum, Associate Professor, Department of Paediatric Nephrology, Bangabandhu Sheikh Mujib Medical University, Dhaka

\section{Correspondence}

Dr. Md. Rafiqul Islam, Associate Professor, Department of Paediatrics, Shaheed Shurawardy Medical College,Sher-E-Bangla Nagar, Dhaka-1207, Bangladesh. Email: rafiq.1956@yahoo.com; Cell phone: +8801715067652 
height. Consecutive 3 measurements revealed BP 125/80mm of $\mathrm{Hg}, 120 / 90 \mathrm{mmof} \mathrm{Hg}, 120 / 85 \mathrm{mmofHg}$, all were above 95 th percentile. There was no difference in BP in both upper and lower limbs. His weight was $37 \mathrm{Kg}$, above 50th percentile, height was $132 \mathrm{~cm}$, on 10 th percentile and BMI was 21.2, which fell above 90th percentile according to Centre for Disease Control and Prevention growth chart 2000. Examination of eyes and other systems revealed normal. His haemogram showed normal picture, routine biochemistry revealed random blood sugar $5.6 \mathrm{mmol} / \mathrm{L}$, lipid profile serum cholesterol $143 \mathrm{mg} / \mathrm{dl}$, serum HDL cholesterol $41 \mathrm{mg} / \mathrm{dl}$, and serum LDL cholesterol $79 \mathrm{mg} / \mathrm{dl}$, serum triglycerides $111 \mathrm{mg} / \mathrm{dl}$. Screening for renal function, Urine routine microscopic examination was normal, serum electrolyte normal (serum sodium-138mmol/1, serum potassium $-4.5 \mathrm{mmol} / 1$, serum chloride- $97 \mathrm{mmol} / 1$, serum TCO2-27mmol/1), serum creatinine $0.58 \mathrm{mg} / \mathrm{dl}$, his ECG and Echocardiography also normal, screening for his endocrine diseases, serum aldosterone normal, 24 hours urinary Vanilmandelic Acid was $3.1 \mathrm{mg}$, which is normal. Screening for vasculitis including Serum C3, C4, ANA, Anti-Ds DNA, pANCA, cANCA were normal. Ultrasonography of abdomen was normal, color Doppler ultrasonography of renal vessels showed normal, and CT scan of abdomen was also normal including normal adrenal gland and sympathetic chain. Then the child was treated with losartan potassium tab., then gradually BP become bellow 90th percentile. Ultimately the child was discharged when his blood pressure was $100 / 70 \mathrm{~mm}$ of $\mathrm{Hg}$, which was on 50th percentile with counselling and advised for follow up.

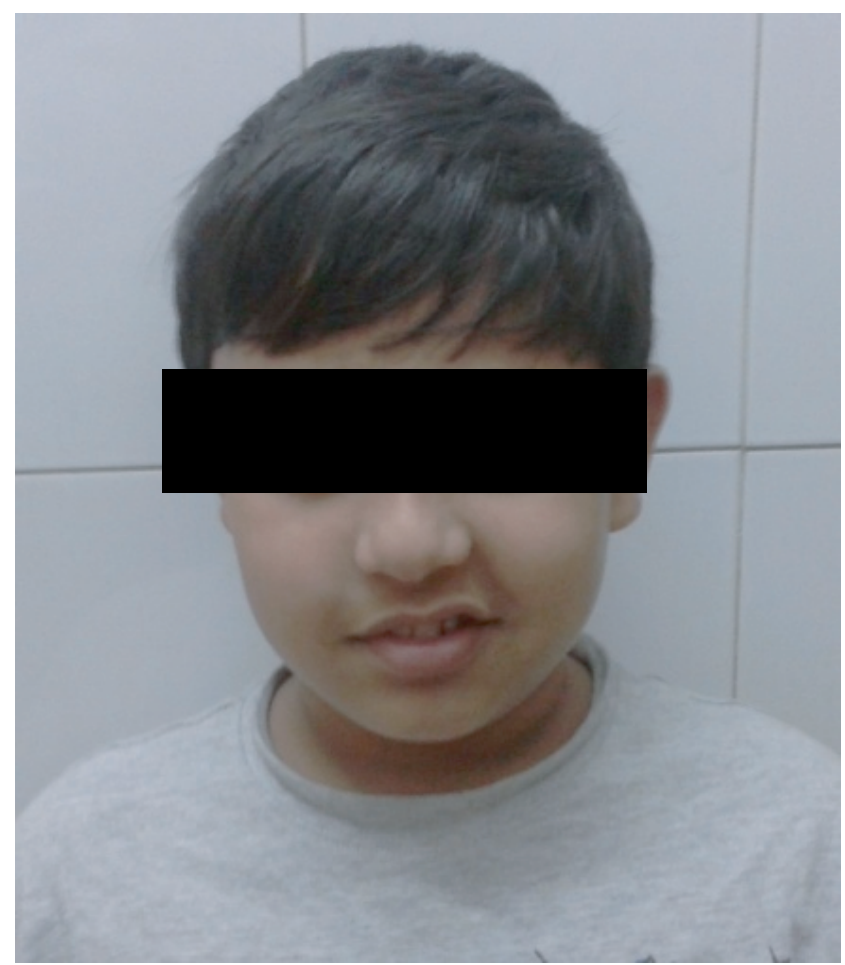

Figure I: The boy presented with childhood hypertension

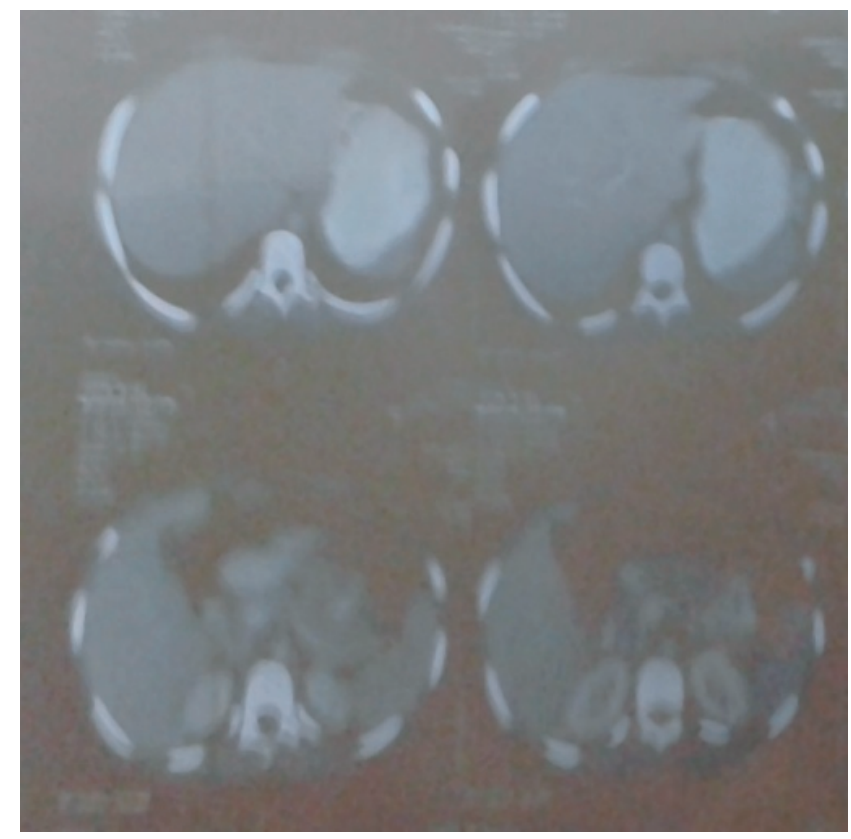

Figure II: CT scan of abdomen shows normal

\section{Discussion}

According to the criteria of the Fourth Report on the Diagnosis Evaluation of hypertension in children is defined as systolic BP (SBP) and diastolic BP (DBP) less than 90th percentile for age, sex and height, whereas hypertension is defined as SBP and/or DBP persistently 95th percentile or more, measured on at least three separate occasions with the auscultatory method ${ }^{9}$. The pathogenesis of essential HTN is likely to be multifactorial. Obesity is the main contributor. Other factors are insulin resistance, activation of sympathetic nervous system, sodium homeostasis, renin angiotensin system and genetic factors ${ }^{8,11}$. According to the Centre for Disease Control and Prevention growth chart 2000, overweight is classified as BMI above 85th to 95th percentile, while in obesity BMI is above 95th percentile. Recent studies in United States and European countries show that prevalence of overweight and obesity is increasing ${ }^{12}$. In a meta analysis in India shows prevalence of overweight is $12.0 \%$ and obesity is $3.0 \%{ }^{13}$. The metabolic syndrome is almost always encountered in obese children and is associated with hyperlipidemia, insulin resistance and HTN. The sympathetic nervous system (SNS) plays a role in energy balance and metabolic syndromes as fasting suppresses and meal ingestion induces SNS activity ${ }^{14}$. Central fat distribution is also associated with disturbance in the hypothalamic-pituitaryadrenal axis, suggesting that a disturbed axis might be implicated in the development of the metabolic syndrome $^{15}$. In a recent systemic review and meta analysis, the evidence was found to be strong for BP tracking from childhood to adulthood ${ }^{16}$. HTN is the major risk factor for atherosclerosis, leading to the development of cardiovascular disease (CVD). HTN is also a risk factor for the progression to end stage renal disease, thus early detection and intervention are crucial. So, childhood HTN 
increases the risk of cardiovascular morbidity and mortality. Another important contributing factor is a strong family history ${ }^{2}$. About $50 \%$ of hypertensive children have family history of HTN and the reason is thought to be due to shared environmental exposures (obesity, salt intake, life style etc.) and genetic susceptibility ${ }^{17}$. The effect of physical activity in the prevention and treatment of HTN is well established in adult, but in children and adolescents however are conflicting ${ }^{18,19}$. In obese children the amount of time spent watching television is associated with both HTN and the severity of obesity ${ }^{20}$.

In this patient, he had strong family history of HTN; he was overweight \& ate fast food and he lived sedentary lifestyle. Children and young adolescent with BP >90th percentile for age have 3 fold greater likelihood of becoming adult with HTN compared to their peers with BP at 50 th percentile 8 .

\section{Conclusion}

Now a day due to food habit and life styles, like other non communicable diseases essential hypertension is also coming up in children. So every child, who have headache BP should be measured in outdoor clinic or in inpatient department. If BP found raised, then secondary causes should be excluded as well as complications to be evaluated and treated. Primary HTN needs lifelong attention with pharmacological and non pharmacological approach like change of food habit and lifestyle modification.

\section{References}

1. Sanjad SA, etiology of hypertension in children and adolescents, J Med Liban 2010; 58(3): 142-5.

2. http://highbloodpressure.about.com/od/lifeafterdiagnosis/tp/hypertensionrisk-in-children.htm.

3. Din-Dzietham, R., Liu, Y., Bielo, High blood pressure trends in children and adolescents in a national surveys, 1963 to 2002, Circulation 2007; 116: 1488-1496.

4. Sorof JM, Lai D, Turner J et al, Overweight ethnicity, and the prevalence of hypertension in school-aged children. Paediatrics 2004; 113: 475-82.

5. Paradis G, Lambert M, O'Loughlin J et al, Blood pressure and adiposity in children and adolescents. Circulation 2004; 110: 1832-38.

6. Arar MY, Hogg RJ et al, Etiology of sustained hypertension in children in the southern united states. Pediatric nephrol 1994; 8: 186-89.

7. Chadha SL, Tandon R et al, A epidemiological study of blood pressure in school children(5-14 years) in Delhi. Indian Heart J 1999; 51:178-82.

8. Bernstain D, Systemic hypertension in: Nelson's Textbook of Pediatrics. 19th edition, Kliegman RM, Stanton BF, editors: Philadelphia: Mosby Elsevier; 2010, 1988-95.

9. Barua C, Hussain MZ, Hypertension in children: a review, Bangladesh J Child Health, 2011; 35(3): 108-117.

10. Lawes CM, Vander Horn S et al, International society of hypertension. Global burden of blood pressure related disease, 2001. Lancet 2008; 371: 1513-8.

11. Singh M, Mensah GA et al, Pathogenesis and clinical physiology of hypertension, Cardiol Clin 2010; 28: 545-59.

12. Valdés Pizarro J, Royo-Bordonand MA (2012) Prevalence of childhood obesity in spain: National Health Survey 2006-2007. Nutr Hosp 27: $154-60$.

13. Midha T, Nath B et al, Childhood obesity in India: a meta analysis. Indian J Pediatr 2012; 79: 945-48.

14. Mohamed AV, Bulmer $\mathrm{K}$ et al, Beta-adrenergic regulation of proinflammatory cytokines in humans. Int $\mathrm{J}$ Obes Relat Metab Disord 2000; 24 [suppl 2]: s154-s155.

15. Chrousos GP, The hypothalamic-pituitary-adrenal axis and immunemediated inflammation. N Eng J Med 1995; 332: 1351-62.

16. Chen, X. and Wang,Y. Tracking of blood pressure from childhood to adulthood: a systemic review and meta regression analysis. Circulation 2008; 117: 3171-80.

17. Jung FF, Ingelfinger JR. Hypertension in childhood and adolescence. Pediatr Rev 1993; 14: 169-79.

18. Whelton SP, Chin A et al, Effect of aerobic exercise on blood pressure: a meta analysis of randomised, controlled trials, Ann Intern Med 2002; 136:493-503.

19. Klesges RC, Haddock $\mathrm{CK}$ et al, A multimethod approach to the measurement of childhood physical activity and its relation to blood pressure and body weight. J Pediatr 1990; 116: 888-93.

20. Boreham C, Twisk J et al, Relationship between the development of biological risk factors for coronary heart disease and lifestyle parameters during adolescence: The Nortern Ireland Hearts Project. Public Health 1999; 113: 7-12. 